\title{
Gambaran Status Nutrisi pada Pasien Tuberkulosis di Rumah Sakit Umum Pusat Hasan Sadikin Bandung
}

\author{
Farah Eka Salsabela ${ }^{1}$, Hendarsyah Suryadinata ${ }^{2}$, Insi Farisa Desy Arya ${ }^{3}$
}

${ }^{1}$ Fakultas Kedokteran, Universitas Padjadjaran

${ }^{2}$ Divisi Respirologi dan Penyakit Kritis, Departemen Ilmu Penyakit Dalam, Fakultas Kedokteran, Universitas Padjadjaran/ Rumah Sakit Umum Pusat Dr. Hasan Sadikin Bandung

${ }^{3}$ Departemen Ilmu Kesehatan Masyarakat, Fakultas Kedokteran, Universitas Padjadjaran

\begin{abstract}
Abstrak
Proporsi gizi kurang pada pasien tuberkulosis (TB) dewasa masih tinggi di negara-negara berkembang. Hal ini akan menyebabkan permasalahan kesehatan yang lebih serius, jika tidak teridentifikasi dengan segera. Penelitian ini bertujuan untuk mengetahui gambaran status nutrisi berdasarkan karakteristik pasien TB dewasa rawat jalan di Klinik Directly Observed Treatment Short-course (DOTS) Rumah Sakit Hasan Sadikin (RSHS). Penelitian ini menggunakan metode potong lintang. Data diambil dari 107 rekam medis online (Sistem Informasi Rumah Sakit: Admission dan Klinik Rawat Jalan) dan Kartu Pengobatan Pasien TB (Formulir TB.01) pada pasien TB dewasa rawat jalan dalam periode Juni 2015 hingga Oktober 2016. Informasi mencakup identitas pasien (nama, nomor rekam medis, umur, pekerjaan, pendidikan, dan sistem pembayaran), diagnosis, serta berat dan tinggi badan yang diukur saat didiagnosa mengalami TB. Proporsi gizi kurang adalah tiga puluh lima persen (35\%). Enam puluh dua persen $(62 \%)$ pasien tidak bekerja dan sembilan puluh persen $(90 \%)$ pasien terdaftar sebagai pasien asuransi kesehatan. Enam puluh lima persen $(65 \%)$ pasien mengalami gizi kurang dan tidak bekerja. Proporsi gizi kurang masih cukup tinggi (35\%) pada pasien-pasien yang mengalami TB. Hasil dari penelitian ini dapat memberikan landasan penatalaksanaan yang lebih efektif dan meningkatkan angka kesembuhan pada pasien TB dewasa
\end{abstract}

Kata Kunci: Gizi kurang, pasien rawat jalan, tuberkulosis

\section{Tuberculosis Patients' Nutritional Status in Hasan Sadikin General Hospital Bandung}

\begin{abstract}
The proportion of undernutrition among adult tuberculosis (TB) patients is high in developing countries. This can have impact to more serious public health problems if adult TB patients are not identified early. The aim of this study is to determine nutritional status proportion based on adult TB outpatients' characteristics in Directly Observed Treatment Short-course (DOTS) Clinic, Hasan Sadikin General Hospital Bandung.This study was undertaken using cross sectional method. Data were collected from 107adult TB outpatients' online medical records (Hospital Information System: Admission and Outpatient Clinic) and TB Patient Treatment Forms (TB.01 Form) in June 2015 to October 2016 period. The information includedpatient's identity (name, medical record number, age, occupation, educational background, and payment system), diagnosis, and body weightand height measured at the time of diagnosis. The proportion of undernutrition was thirty five percent $(35 \%)$. Sixty two percent $(62 \%)$ subjects were unemployed and ninety percent $(90 \%)$ subjects were registered as health insurance coverage's patients. Sixty five percent $(65 \%)$ subjects had undernutrition and were unemployed.The proportion of undernutrition among TB patients was high (35\%). These findings can support more effective treatment, notably nutritional management, and increase adult TB patients' recovery rate
\end{abstract}

Keywords: Outpatiens, tuberculosis, undernutrition

Korespondensi:

Farah Eka Salsabela

Fakultas Kedokteran, Universitas Padjadjaran

Jl. Raya Bandung-Sumedang km 21 Jatinangor

Mobile : 081322277341

Email : faraheka.96@gmail.com 


\section{Pendahuluan}

Tuberkulosis (TB) merupakan suatu masalah kesehatan umum utama dan menjadi salah satu ancaman terbesar di dunia, khususnya bagi negara-negara berkembang. ${ }^{12}$ TB menjadi salah satu penyebab utama kematian pada orang dewasa di negara-negara berkembang, dan menjadi permasalahan dalam bidang kesehatan yang paling penting di Indonesia. ${ }^{3}$ Jumlah pasien TB pada tahun 2014 mencapai 9,6 juta orang di seluruh dunia; terdiri dari 5,4 juta pria; 3,2 juta wanita, dan 1 juta anak-anak. ${ }^{2}$ TB menyebabkan kematian pada 1,5 juta orang, yang terdiri dari 890.000 pria, 480.000 wanita, dan 140.000 anakanak di tahun yang sama. ${ }^{2}$

Hal ini menjadi perhatian utama dunia, khususnya Indonesia, yang merupakan negara dengan jumlah penderita TB terbesar di dunia. ${ }^{2}$ World Health Organization (WHO) menyatakan bahwa Indonesia berada di peringkat kedua penderita TB terbesar di dunia dengan prevalensi 647 per 100.000 pada tahun $2014 .^{2}$ Pedoman Nasional Pelayanan Tuberkulosis 2013 menunjukkan bahwa Indonesia menempati urutan keempat dunia setelah India, Cina, dan Afrika Selatan, dengan 0,38-0,54 juta kasus pada tahun $2011 .{ }^{4}$

Gizi kurang sering dijumpai pada pasien yang menderita TB. Pendataan status nutrisi pada pasien tersebut masih belum terdokumentasi dengan baik. ${ }^{3}$ Prevalensi gizi kurang pada pasien TB dewasa tinggi, khususnya negara-negara berkembang, termasuk Indonesia. ${ }^{5}$ Dua puluh lima persen pasien TB yang terdokumentasi dalam kasus baru TB mengalami gizi kurang di seluruh dunia. ${ }^{5}$ Penelitian menunjukkan bahwa seseorang yang mengalami TB aktif menyebabkan penurunan asupan nutrisi, sehingga terjadi penurunan berat badan. ${ }^{5}$

Status nutrisi yang buruk pada pasien TB disebabkan oleh anoreksia, absorpsi nutrisi terganggu, atau peningkatan katabolisme tubuh. ${ }^{4}$ Gizi kurang pada pasien TB jika tidak teridentifikasi segera akan menyebabkan permasalahan kesehatan yang lebih serius, seperti peningkatan angka mortalitas. ${ }^{5}$

Penelitian penatalaksanaan TB secara nutrisi belum banyak dilakukan. Sebagian besar penelitan penatalaksanaan TB membahas tentang pengobatan TB secara farmakologi. Penelitian ini dilakukan mengetahui gambaran status nutrisi berdasarkan karakteristik pasien TB dewasa rawat jalan di Klinik Directly Observed Treatment Short-course (DOTS) Rumah Sakit Hasan Sadikin (RSHS).

\section{Metode}

Penelitian ini menggunakan desain potong lintang yang dilakukan di Klinik DOTS RSHS Kota Bandung. Penelitian ini telah disetujui oleh Komite Etik Penelitian Kesehatan RSHS. Subjek pada penelitian ini adalah pasien TB paru dan ekstra paru dewasa yang sedang menjalani rawat jalan di Klinik DOTS RSHS. Pengambilan data dilakukan pada Bulan September - November 2016 tiap hari Selasa Rabu, dan Kamis. Hari Selasa dan Rabu merupakan jadwal pemeriksaan dan pengambilan obat untuk pasien TB dewasa paru dan ekstraparu, sedangkan hari Kamis merupakan jadwal pemeriksaan dan pengambilan obat untuk pasien TB dewasa ekstra paru di Klinik DOTS RSHS.

Metode pengambilan sampel adalah consecutive sampling dan menggunakan 107 (seratus tujuh) data rekam medis online pasien TB dewasa dan Kartu Pengobatan Pasien TB (TB. 01). Penentuan besar sampel menggunakan penghitungan jumlah sampel minimal untuk penelitian deskriptif. Penelitian ini menggunakan $\alpha=0.5 \%$, sehingga nilai $Z \alpha=1.96$. Peneliti juga menetapkan nilai $\mathrm{P}=0.5$ karena proporsi variabel dari kepustakaan tidak ditemukan. Nilai d yang ditetapkan oleh peneliti adalah $10 \%$. Nilai-nilai tersebut dimasukkan ke dalam rumus besar sampel dan didapatkan hasil 96,04 dan dibulatkan ke atas menjadi 97, sehingga didapatkan jumlah sampel minimal yang dibutuhkan dalam penelitian ini adalah 97 subjek.

Kriteria inklusi adalah pasien TB dewasa berusia $\geq 14$ tahun dan ditegakkan diagnosis TB dalam periode Juni 2015 hingga Oktober 2016. Seratus tujuh dari seratus dua puluh pasien memenuhi kriteria tersebut. Pasien yang mengalami gangguan status nutrisi sebelum ditegakkan diagnosis TB dan memiliki penyakit penyerta, seperti Human Immunodeficiency Virus/Acquired Immunodeficiency Syndrome (HIV/AIDS), Systemic Lupus Erythematosus (SLE), dan Diabetes Mellitus (DM) dikeluarkan dari penelitian ini. Tiga belas pasien dikeluarkan dari penelitian ini, terdiri dari lpasien TB dewasa dengan DM, dua pasien TB dewasa dengan SLE, dan sepuluh pasien TB dengan HIV/AIDS.

Pengisian Kartu Pengobatan Pasien TB (TB.01) dilakukan setelah suspek TB ditegakkan diagnosis sebagai pasien TB. Dokter atau perawat melakukan pencatatan dengan mengisi Kartu Pengobatan Pasien TB (TB.01) untuk dapat mengikuti perkembangan penyakit dan hasil pengobatan pasien TB. Pengisian Kartu Pengobatan Pasien TB (TB.01) diikuti oleh pengisian Kartu Identitas Pasien TB (TB.02) dan disimpan di Poli DOTS RSHS. Kartu Pengobatan 
Pasien TB (TB.01) merupakan bagian dari program Penanggulan TB Nasional yang dibuat oleh Kementerian Kesehatan Republik Indonesia. Data yang digunakan adalah identitas pasien (nama, nomor rekam medis, umur, pekerjaan, pendidikan, dan sistem pembayaran), diagnosis (TB paru/ekstraparu), serta berat badan dan tinggi badan yang dicatat saat ditegakkan diagnosis TB. Berat dan tinggi badan diukur saat pencatatan data di Kartu Pengobatan Pasien TB berlangsung dan sebelum pengambilan Obat Anti TB (OAT). Data berat badan pasien diambil dari Kartu Pengobatan Pasien TB (TB.01) dan tinggi badan pasien diukur oleh peneliti di Klinik DOTS RSHS.

Data mengenai status nutrisi didapatkan melalui perhitungan Indeks Masa Tubuh (IMT) dengan menggunakan program statistik. Status nutrisi kemudian ditampilkan dalam bentuk tabel berdasarkan jenis kelamin, kelompok usia (10-19 tahun, 20-29 tahun, 30-39 tahun, 40-49 tahun, 50-59 tahun, 60-69 tahun, dan $\geq 70$ tahun), diagnosis (TB paru dan ekstraparu), pekerjaan (tidak bekerja, buruh, petani, swasta, PNS, dan lain-lain), pendidikan (pendidikan anak usia dini, pendidikan dasar (kelas 1-6), pendidikan dasar (kelas 7-9), pendidikan menengah (kelas 10-12), dan pendidikan tinggi), dan sistem pembayaran (umum dan asuransi kesehatan).

\section{Hasil}

Karakteristik Subjek Penelitian; Hasil penelitian menunjukkan bahwa subjek perempuan lebih banyak daripada laki-laki yaitu sebanyak 68 $(64 \%)$ pasien. Kategori usia terbanyak dari penelitian adalah 20-29 tahun yaitu sebanyak $40(37 \%)$ pasien. Usia termuda adalah 16 tahun dan usia tertua adalah 80 tahun. Sebanyak 32 (35\%) pasien dengan TB paru dan 71 pasien (73 $\%$ ) dengan TB ekstraparu. Pekerjaan terbanyak adalah tidak bekerja yaitu 66 (62\%) pasien. Latar belakang pendidikan terbanyak adalah pendidikan menengah (kelas 10-12) yaitu 70 (65 $\%$ pasien. Karakteristik demografis dan klinis subjek penelitian selengkapnya dapat dilihat pada Tabel 1 .

Status Nutrisi Subjek Penelitian; Indeks Massa Tubuh (IMT) terbanyak dari subjek penelitian adalah normal weight (IMT 18,5-22,9 $\mathrm{kg} / \mathrm{m} 2)$ yaitu sebanyak $44(41 \%)$ pasien. IMT underweight $(<18,5 \mathrm{~kg} / \mathrm{m} 2)$ menduduki posisi ke-2 terbanyak yaitu $37(35 \%)$ pasien. Status nutrisi subjek penelitian selengkapnya dapat dilihat pada Tabel 2
Tabel 1 Karakteristik Demografis dan Klinis Subjek Penelitian $(n=107)$

\begin{tabular}{lc}
\hline Karakteristik & \\
\hline Jenis Kelamin, $\mathrm{n}(\%)$ & $39(36)$ \\
Laki-laki & $68(64)$ \\
Perempuan & \\
& $31(16-80)$ \\
Usia (tahun), median (min-maks) & \\
& \\
Kategori usia, n (\%) & $11(10)$ \\
10-19 tahun & $40(37)$ \\
20-29 tahun & $22(21)$ \\
30-39 tahun & $22(21)$ \\
$40-49$ tahun & $9(8)$ \\
$50-59$ tahun & $1(1)$ \\
$60-69$ tahun & $2(2)$ \\
$\geq 70$ tahun &
\end{tabular}

Bentuk TB, n(\%)

TB paru

TB ekstraparu

Pekerjaan, n $(\%)$

Tidak bekerja (IRT, mahasiswa)

Buruh

Petani

Swasta

PNS

Lain-lain

Pendidikan, $\mathrm{n}(\%)$

Pendidikan anak usia dini

Pendidikan dasar (Kelas 1-6)

Pendidikan dasar (Kelas 7-9)

Pendidikan menengah (Kelas 10-12)

Pendidikan tinggi

Cara bayar, $\mathrm{n}(\%)$

Umum

Asuransi kesehatan $96(90)$

Keterangan:

TB: Tuberkulosis; IRT: Ibu Rumah Tangga; PNS: Pegawai Negeri Sipil 
Tabel 2 Status Nutrisi Subjek Penelitian $(n=107)$

\begin{tabular}{|c|c|c|c|}
\hline Variabel & IMT & Variabel (Pekerjaan) & Variabel (Pendidikan) \\
\hline IMT, median (min-maks) & $20(13-29)$ & & \\
\hline IMT, n (\%) & & Pekerjaan, n (\%) & Pendidikan, n (\%) \\
\hline \multirow[t]{6}{*}{ Underweight $(<18,5 \mathrm{~kg} / \mathrm{m} 2)$} & $37(35)$ & Tidak bekerja: 24 (65) & Anak usia dini: $0(0)$ \\
\hline & & Buruh: $2(5)$ & Kelas 1-6: $0(0)$ \\
\hline & & Petani: $0(0)$ & Kelas 7-9: 5 (14) \\
\hline & & Swasta: 11 (30) & Kelas 10-12: 27 (73) \\
\hline & & PNS: $0(0)$ & Tinggi: 5 (14) \\
\hline & & Lain-lain: $0(0)$ & \\
\hline \multirow[t]{6}{*}{ Healthy weight $(18,5-22.9 \mathrm{~kg} / \mathrm{m} 2)$} & $44(41)$ & Tidak bekerja: 25 (57) & Anak usia dini: $0(0)$ \\
\hline & & Buruh: 1 (2) & Kelas 1-6: 1 (2) \\
\hline & & Petani: $0(0)$ & Kelas 7-9: 7 (16) \\
\hline & & Swasta: 13 (30) & Kelas 10-12: 27 (61) \\
\hline & & PNS: 4 (9) & Tinggi: $9(21)$ \\
\hline & & Lain-lain: 1 (2) & \\
\hline \multirow[t]{6}{*}{ Overweight $(23-24,9 \mathrm{~kg} / \mathrm{m} 2)$} & $13(12)$ & Tidak bekerja: 9 (69) & Anak usia dini: $0(0)$ \\
\hline & & Buruh: $0(0)$ & Kelas 1-6: $0(0)$ \\
\hline & & Petani: $0(0)$ & Kelas 7-9: 3(23) \\
\hline & & Swasta: 4 (31) & Kelas 10-12: 9 (69) \\
\hline & & PNS: $0(0)$ & Tinggi: $1(8)$ \\
\hline & & Lain-lain: $0(0)$ & \\
\hline \multirow[t]{6}{*}{ Obese Class I (25-29,9 kg/m2) } & $13(12)$ & Tidak bekerja: 8 (61) & Anak usia dini: $0(0)$ \\
\hline & & Buruh: $0(0)$ & Kelas 1-6: 2 (15) \\
\hline & & Petani: $0(0)$ & Kelas 7-9: 3 (23) \\
\hline & & Swasta: 4 (31) & Kelas 10-12: 7 (54) \\
\hline & & PNS: 1 (8) & Tinggi: $1(8)$ \\
\hline & & Lain-lain: $0(0)$ & \\
\hline \multirow[t]{6}{*}{ Obese Class II ( $\geq 30 \mathrm{~kg} / \mathrm{m} 2)$} & $0(0)$ & Tidak bekerja: $0(0)$ & Anak usia dini: 0 (0) \\
\hline & & Buruh: $0(0)$ & Kelas 1-6: $0(0)$ \\
\hline & & Petani: $0(0)$ & Kelas 7-9: $0(0)$ \\
\hline & & Swasta: $0(0)$ & Kelas 10-12: $0(0)$ \\
\hline & & PNS: $0(0)$ & Tinggi: $0(0)$ \\
\hline & & Lain-lain: $0(0)$ & \\
\hline
\end{tabular}

IMT: Indeks Massa Tubuh

\section{Pembahasan}

TB sering dihubungkan dengan gizi kurang dan kekurangan berat badan. ${ }^{6}$ TB dapat menurunkan asupan energi yang disebabkan oleh perubahan metabolisme akibat penurunan nafsu makan sebagai bagian dari respon inflamasi dan imun. ${ }^{67}$
Suatu penelitian di Uganda menemukan bahwa terjadi penurunan sejumlah nutrisi, terdiri dari makronutrisi dan mikronutrisi, seperti karbohidrat, energi, protein, lemak total, kalsium, vitamin A, dan folat pada pasien TB. ${ }^{7}$ Gizi kurang merupakan faktor risiko penting terhadap $\mathrm{TB}$, karena Cell-Mediated Immunity (CMI) 
merupakan kunci utama dalam melawan TB. ${ }^{8}$ Populasi dengan nutrisi buruk memiliki risiko tinggi terhadap TB. ${ }^{8}$ Penelitian ini menunjukkan bahwa $44(41 \%)$ pasien memiliki IMT normal weight (IMT 18,5-22.9 kg/m²) dengan 18 (41\%) subjek diantaranya memiliki IMT $<20 \mathrm{~kg} / \mathrm{m}^{2}$ dan 37 (35\%) pasien memiliki IMT underweight (IMT $<18,5 \mathrm{~kg} / \mathrm{m}^{2}$ ). Penelitian di Addis Ababa, Ethiopia menunjukkan hasil serupa, yaitu 39,7 \% pasien TB dewasa mengalami gizi kurang. ${ }^{5}$

TBmerupakanmasalah kesehatanumumutama yang disebabkan oleh kemiskinan dan cenderung dialami oleh masyarakat dengan ekonomi kelas bawah. ${ }^{910}$ Hal tersebut menyebabkan penurunan kualitas hidup, sehingga banyak pasien TB yang mengalami gizi kurang. ${ }^{9}$ Kemiskinan, nutrisi buruk, dan kekurangan cadangan makanan merupakan faktor penting terjadinya TB pada seseorang atau suatu populasi.11 Hasil penelitian ini menunjukkan bahwa 66 (62\%) subjek tidak bekerja dan $32(30 \%)$ subjek bekerja sebagai wiraswasta. Hasil penelitian ini menunjukkan juga bahwa 96 (90 \%) subjek menggunakan asuransi kesehatan. Sebanyak $96(90 \%)$ adalah peserta Badan Penyelenggara Jaminan Sosial (BPJS Kesehatan). Penelitian di Addis Ababa, Ethiopia menunjukkan hasil serupa, bahwa 31,5 $\%$ pasien TB dewasa tidak bekerja dan $28,0 \%$ pasien TB dewasa bekerja sebagai wiraswasta. ${ }^{5}$

Faktor budaya dapat memengaruhi asupan nutrisi pada wanita dalam suatu keluarga, seperti distribusi makanan yang tidak merata dalam keluarga, atau laki-laki memiliki kesempatan yang lebih besar dibandingkan perempuan dalam mengonsumsi makanan yang lebih bervariasi dan lebih berkualitas di luar rumah, seperti restoran, dibandingkan perempuan. ${ }^{7}$ Hal tersebut disebabkan oleh beberapa faktor, seperti kebiasaan perempuan yang dilatih untuk mengurangi konsumsi makanan, mendahulukan anggota keluarga tertentu untuk makan terlebih dulu, dan memberikan makanan terbaik untuk laki-laki.?

Insidensi tinggi pada gizi kurang dapat disebabkan oleh beberapa hal, seperti kebiasaan makanan buruk, ketidaktahuan mengenai asupan makanan bergizi dan seimbang, dan latar belakang pendidikan yang rendah. ${ }^{12}$ Hasil penelitian ini juga menunjukkan bahwa 91 (85\%) pasien memiliki latar pendidikan pendidikan menengah (kelas 10-12) ke bawah dan 70 (65\%) diantaranya memiliki latar pendidikan menengah (kelas 10-12). Berihun Dargie dan kawan-kawan menunjukkan hasil serupa, yaitu 43,1\% pasien TB dewasa memiliki latar belakang pendidikan menengah (kelas 9-12). ${ }^{5}$

Pasien TB mengalami beban ganda akibat pendapatan berkurang dan pengeluaran meningkat. ${ }^{11}$ Hal tersebut berdampak pada peningkatan kebutuhan energi serta pemburukan kondisi pasien dan persedian makanan. ${ }^{611}$ Body wasting, meliputi penurunan pada BMI, menjadi ciri khas dari pasien TB. ${ }^{9}$ Wasting menyebabkan terjadinya gangguan pada fungsi tubuh, sehingga jika dibiarkan akan menyebabkan kematian pada pasien TB. ${ }^{9}$ Pasien TB dapat mengalami wasting selama berbulan-bulan, bahkan setelah pasien mulai menjalani terapi OAT. ${ }^{7}$ Gizi kurang meningkatkan risiko perkembangan dari infeksi TB menjadi penyakit TB aktif dan meningkatkan risiko kematian. ${ }^{11}$

Gizi kurang berhubungan dengan pemburukan fungsi tubuh dan merupakan faktor resiko utama terhadap morbiditas dan mortalitas di seluruh dunia dan berkontribusi sebagai faktor risiko yang lebih besar terhadap TB dibandingkan HIV/AIDS dalam populasi. ${ }^{913}$ Gizi kurang meningkatkan risiko kematian secara signifikan. ${ }^{14} \mathrm{M}$ Naseer dan kawan-kawan menunjukkan bahwa 8,6\% subjek mengalami resiko gizi kurang selama 7 tahun follow-up dan 34,6\% subjek meninggal akibat gizi kurang. ${ }^{14} \mathrm{M}$ Naseer dan kawan-kawan menjelaskan lebih lanjut bahwa angka harapan hidup pada pasien gizi kurang adalah 18,7 $\%{ }^{14}$ Tiga penelitian menunjukkan IMT rendah berkaitan dengan peningkatan resiko kematian pada pasien TB. ${ }^{15}$

Hal ini menunjukan bahwa gizi kurang berhubungan dengan peningkatan resiko mortalitas pada pasien TB. ${ }^{15}$ Hal ini juga menunjukkan bahwa status nutrisi dapat digunakan sebagai prognosis pasien tuberkulosis yang menjalani rawat jalan.

Keterbatasan dalam penelitian ini adalah jumlah subjek penelitian terbatas, yaitu 120 pasien, sehingga hasilnya belum dapat digeneralisasikan pada kelompok subjek dengan jumlah yang besar. Penelitian ini hanya meneliti status gizi yang dihitung berdasarkan IMT, masih terdapat beberapa teknik lain yang berhubungan dengan status nutrisi yang belum diteliti, seperti pemeriksaan antropometri dan laboratorium.

Simpulan; Gizi kurangpada pasien TB dewasa sebesar lebih dari sepertiga saat ditegakkan diagnosis mengalami TB. Penilaian status dan asupan nutrisi rutin serta konseling mengenai asupan nutrisi (makronutrisi dan mikronutrisi) bergizi dan seimbang serta mencukupi Angka Kecukupan Gizi (AKG) sebaiknya menjadi bagian dari penatalaksanaan TB.

Penelitian lebih lanjut perlu dilakukan agar dapat memberikan penatalaksanaan yang lebih efektif, khususnya penatalaksanaan nutrisi,dan meningkatkan angka kesembuhan pada pasien TB, khususnya pada pasien TB dewasa di Klinik TB RSHS. 


\section{Daftar Pustaka}

1. Mrinal Pal, Subinay Datta, Ritabrata Mitra. Tuberculosis is Associated with Low Levels of Vitamin D. World Journal of Pharmacy and Pharmaceutical Sciences. 2014; 3(2): 1449-1463.

2. World Health Organization. Global Tuberculosis Report. 2015.

3. Kementerian Kesehatan Republik Indonesia. Pedoman Nasional Pelayanan Kedokteran Tata Laksana Tuberkulosis. 2013.

4. Elvina Karyadi, Werner Schultink, Ronald H. H. Nelwan, Rainer Gross, Zulkifli Amin, Will M. V. Dolmans, dkk. Poor Micronutrient Status of Active Pulmonary Tuberculosis Patients in Indonesia. The Journal of Nutrition. 2000; 130: 2953-2958.

5. Berihun Dargie, Gezahegn Tesfaye, Amare Worku. Prevalence and Associated Factors of Undernutrition among Adult Tuberculosis Patients in Some Selected Public Health Facilities of Addis Ababa, Ethiopia: A CrossSectional Study. BioMed Central Nutrition. 2016; 2(7).

6. Meena Mehta. Impact of Nutrition Education on Pulmonary Tuberculosis Patients. Global Journal for Research Analysis. 2016; 5(6):317-320.

7. Ezekiel Mupere, Isabel M Parraga, Daniel J Tisch, Harriet K Mayanja, Christopher C Whalen. Low Nutrient Intake among Adult Women and Patients with Severe Tuberculosis Disease in Uganda: A Cross-Sectional Study. BioMed Central Public Health. 2012; 12: 1050-1057.

8. J. P. Cegielski, D. N. McMurray. The Relationship between Malnutrition and Tuberculosis: Evidence from Studies in Humans and Experimental Animals. 2004; 8(3): 286-298.

9. Nicholas I Paton, Yueh-Khim Chua,
Arul Earnest, Cynthia BE Chee. Randomized Controlled Trial of Nutritional Supplementation in Patients with Newly Diagnosed Tuberculosis and Wasting. The American Journal of Clinical Nutrition. 2004; 80:460-465.

10. Nirali S. Desai, Nestani Tukvadze, Jennifer Frediani, Maia Kipiani, Eka Sanikidze, Memorie M. Nichols, Gautam Hebbar, dkk.. Effects of Sunlight and Diet on Vitamin D Status of Pulmonary Tuberculosis Patients in Tblisi, Georgia. National Institute of Health. 2012; 28(4): 362-366.

11. D. Pedrazzoli, R. M. Houben, N. Grede, S. de Pee, D. Boccia. Food Assistance to Tuberculosis Patients: Lessons from Afghanistan. International Union Against Tuberculosis and Lung Disease. 2016; 6(2): 147-153.

12. Kausik Chatterjee, Sabyasachi Ray, Baladev Das, Dipak Kumar Bhuniya, Siddharta Sankar Dash. Study of the Nutritional Status of High School from Medinipur Sadar Subdivision, Paschim Medinipur District, West Bengal, India. The International Journal of Science and Technoledge. 2015; 137-140.

13. Ulrich E. Schaible, Stefan H. E. Kaufmann. Malnutrition and Infection: Complex Mechanisms and Global Impacts. Public Library of Science Medicine. 2007.

14. M. Naseer, H Forssell , C Fagerstrom. Malnutrition, Functional Ability, and Mortality among Older People Aged $\geq 60$ Years: a 7-year Longitudinal Study. European Journal of Clinical Nutrition. 2015; 70: 399404.

15. Yung-Feng Yen, Pei-Hung Chuang, MuhYong Yen, Shu-Yi Lin, Pei-Chuang, Mei-Jen Yuan, dkk. Association of Body Mass Index with Tuberculosis Mortality. Medicine Wolters Kluwer Health. 2016;95(1). 